\title{
SIMULASI PENERAPAN CHICANE DENGAN MENGGUNAKAN SOFTWARE VISSIM
}

\author{
Naomi Srie Kusumastutie, Pipit Rusmandani, Mohamad Kusuma Pradana, \\ Wisnu Pamungkas, Masayu Silvi Ersamaulia \\ Progam Studi Manajemen Keselamatan Transportasi Jalan \\ Politeknik Keselamatan Transportasi Jalan \\ Jalan Semeru No.3 Kota Tegal, Jawa Tengah 52125 \\ E-mail: naomi@pktj.ac.id
}

\begin{abstract}
Abstrak
Chicane merupakan salah satu perangkat traffic calming yang banyak digunakan di negara maju. Penelitian mengenai efektivitas chicane sebagai perangkat traffic calming telah dilakukan oleh peneliti sebelumnya dengan menggunakan simulasi lapangan. Penelitian ini bertujuan untuk menyediakan alternatif cara simulasi yang lebih efisien dan aman, disamping juga bisa dapat menganalisis Measure of effectiveness (MOE) dengan lebih komprehensif. Dengan menggunakan data sekunder berupa data observasi geometrik jalan, volume kendaraan, komposisi kendaraan, dan kecepatan kendaraan maka dibuatlah model penerapan chicane dengan menggunakan VISSIM. Penelitian ini menghasilkan kesimpulan yang sejalan dengan penelitian sebelumnya. Hal ini menunjukkan bahwa VISSIM dapat digunakan untuk mensimulasikan penerapan traffic calming, dalam hal ini chicane. MOE yang dihasilkan adalah kecepatan setempat, kecepatan tempuh, kepadatan dan tundaan. Dengan demikian terbuka peluang untuk dapat memanfaatkan VISSIM sebagai alat bantu penerapan traffic calming, maupun pengembangan chicane secara khusus.
\end{abstract}

Kata kunci: Chicane, Measure of effectiveness (MOE), traffic calming,VISSIM

\section{PENDAHULUAN}

Kecepatan kendaraan merupakan salah satu faktor yang dapat meningkatkan kemungkinan keterlibatan dalam tabrakan maupun menambah keparahan korban (Global Road Safety Partnership, 2008). Salah satu cara yang dapat digunakan untuk mengelola kecepatan kendaraan adalah dengan melalui pemasangan traffic calming. Salah satu jenis traffic calming adalah chicane yang dapat dipasang di jalan lokal. Penerapan chicane dicatat dapat mengurangi kecepatan sebanyak $8 \mathrm{~km} / \mathrm{jam}$ sampai dengan $21 \mathrm{~km} / \mathrm{jam}$ pada area chicane, dan $2 \mathrm{~km} / \mathrm{jam}$ sampai dengan $10 \mathrm{~km} / \mathrm{jam}$ pada area sekitar chicane. Selain itu, chicanes juga mampu mengurangi volume lalu lintas sebanyak 20\% (Pennsylvania Department of Transportation, 2012). Dengan pengurangan volume sebagai dampak perubahan pemilihan rute oleh pengemudi ini, maka chicane dapat mengembalikan fungsi jalan lokal. Disamping kedua manfaat tersebut, chicane juga dapat menambah estetika pada ruas jalan diterapkannya chicane.

Di Indonesia penerapan chicane telah diatur dalam Pedoman Perencanaan Fasilitas Pengendali Kecepatan Lalu Lintas (Departemen Permukiman dan Prasarana Wilayah, 2004) sebagai adopsi dari UK Department for Transport. Disana disebutkan bahwa chicane merupakan fasilitas pengendali kecepatan lalu lintas yang bertujuan untuk memaksa pengendara menurunkan kecepatan dengan gangguan fisik. 
Gangguan fisik yang dimaksudkan berupa dua atau lebih penyempitan, selang-seling di sisi jalan, sebagai perluasan bahu jalan atau trotoar, untuk membentuk suatu defleksi horisontal. Pada pedoman ini diatur mengenai kriteria lokasi, tipikal desain chicane, spesifikasi material, serta kebutuhan rambu dan marka untuk chicane.

Dengan melihat adanya best practice penerapan chicane di negara maju dan untuk memberikan alternatif jenis traffic calming di Indonesia, Ersamaulia (2018) telah meneliti mengenai efektivitas penerapan chicane di Indonesia dengan mengambil studi kasus di Jalan Pemuda Kabupaten Kebumen dengan metode simulasi lapangan (field simulation). Dua model chicane diterapkan secara bergantian di ruas jalan tersebut, yaitu chicane model 1 yang dibuat menurut model chicane dari Pedoman Perencanaan Fasilitas Pengendali Kecepatan Lalu Lintas (Departemen Permukiman dan Prasarana Wilayah, 2004) dan chicane model 2 yang dibuat menurut model chicane dari Pennsylvania's Traffic Calming Handbook (Pennsylvania Department of Transportation, 2012).

Berdasarkan hasil penelitian tersebut, chicane terbukti efektif untuk mereduksi kecepatan kendaraan (Ersamaulia, 2018). Pada penerapan chicane model 1, Kecepatan p85 kendaraan berkurang dari $55 \mathrm{~km} / \mathrm{jam}$ menjadi $44 \mathrm{~km} / \mathrm{jam}$ untuk arah utara ke selatan dan dari $53 \mathrm{~km} / \mathrm{jam}$ menjadi $43 \mathrm{~km} / \mathrm{jam}$ untuk arah selatan ke utara. Penurunan kecepatan juga terjadi pada penerapan chicane model 2, yaitu dari kecepatan $55 \mathrm{~km} / \mathrm{jam}$ menjadi $34 \mathrm{~km} / \mathrm{jam}$ untuk arah utara ke selatan dan dari kecepatan $53 \mathrm{~km} / \mathrm{jam}$ turun menjadi $32 \mathrm{~km} / \mathrm{jam}$ untuk arah selatan ke utara. Namun demikian tingkat pelayanan jalan (LOS/Level of Service) yang semula berada pada level B menurun menjadi D pada penerapan chicane model 2 , dan bertahan pada level $B$ pada penerapan chicane model 1. Penentuan LOS dalam penelitian ini menggunakan perhitungan MKJI (Direktorat Jendral Bina Marga, 1997) dan berdasarkan Peraturan Menteri Perhubungan No KM 14 Tahun 2006 Tentang Manajemen dan Rekayasa Lalu Lintas di Jalan (Kementerian Perhubungan, 2006).

Penelitian tersebut telah membuktikan bahwa chicane dapat menjalankan fungsinya dalam mereduksi kecepatan kendaraan, namun masih menyisakan permasalahan yang belum terjawab. Reduksi kecepatan kendaraan yang dihasilkan melalui penerapan chicane model 1 masih cukup jauh dari target kecepatan aman $30 \mathrm{~km} / \mathrm{jam}$ (Kementerian Perhubungan Republik Indonesia, 2015). Di sisi lain, reduksi kecepatan yang dihasilkan oleh chicane model 2 telah mendekati target kecepatan aman tersebut, namun sayangnya berdampak pada turunnya LOS menjadi D. Parameter kinerja jalan yang digunakan dalam penelitian inipun hanyalah LOS sedangkan kinerja jalan hendaknya juga diukur berdasarkan parameter yang lain agar mendapatkan gambaran yang lebih komprehensif. Sebagai catatan, penelitian ini mengukur LOS berdasarkan Peraturan Menteri Perhubungan No KM 14 Tahun 2006 Tentang Manajemen dan Rekayasa Lalu Lintas di Jalan (Kementerian Perhubungan, 2006), sedangkan peraturan tersebut telah diperbarui menjadi Peraturan Menteri Perhubungan No KM 96 Tahun 2015 Tentang Pedoman Pelaksanaan Kegiatan Manajemen dan Rekayasa Lalu Lintas (Kementerian Perhubungan, 2015).

Dengan demikian masih terdapat beberapa beberapa catatan dalam penelitian tersebut, yaitu: 1) penggunaan metode simulasi lapangan yang kurang efisien, 2) masih perlunya perhitungan kinerja ruas jalan dengan parameter yang lain selain tingkat pelayanan, dan 3) perlunya upaya optimalisasi penerapan chicane sehingga 
kinerja jalan dapat terpenuhi baik dari aspek keselamatan maupun aspek kelancaran. Untuk itu masih diperlukan penelitian lanjutan dari penelitian tersebut.

Penelitian ini akan berusaha untuk menjawab beberapa catatan dalam penelitian tersebut, dengan menggunakan bantuan software VISSIM. VISSIM merupakan perangkat lunak simulasi lalu lintas secara mikroskopik (Irawan \& Putri, 2015; Yulianto \& Munawar, 2017). VISSIM sebagai alat bantu pemodelan lalu lintas telah digunakan secara luas. Di Indonesia juga telah banyak diketemukan penelitian mengenai penggunaan VISSIM. Jika dilihat dari lokasinya, maka mayoritas VISSIM digunakan untuk memodelkan arus lalu lintas di simpang (Basrin, Sugiarto, \& Anggraini, 2017; Irawan \& Putri, 2015; Misdalena, 2019; Pamusti, Maulana, \& Herman, 2017; Putra \& Ramanda, 2018; Putri \& Irawan, 2015; Sugiarto, Faisal, \& Reyhan, 2018; Utomo, Yulianyahya, \& Fauziah, 2016). Parameter yang diuji pada penelitian-penelitian tersebut, diantaranya adalah panjang antrian, tundaan, dan kecepatan perjalanan. Selain itu terdapat pula penelitian mengenai penggunaan VISSIM di ruas jalan (Romadhona, 2018; Romadhona \& Fauzi, 2018; Winnetou \& Munawar, 2015) dan jalan tol (Yulianto \& Munawar, 2017). Penelitian-penelitian tersebut menunjukkan bahwa VISSIM telah terbukti cocok untuk dapat digunakan untuk memodelkan karakteristik lalu lintas di Indonesia, terutama dengan kondisi lalu lintas tercampurnya.

Dalam penelitian ini akan dibuat tiga model simulasi, yaitu kondisi eksisting, pada penerapan chicane model 1 , dan chicane model 2. Setelah masing-masing model dibuat maka akan diukur validasi model tersebut dengan membandingkan output VISSIM dengan hasil observasi. Validasi akan dilakukan dengan menggunakan rumus GEH dan MAPE. Dengan model yang telah tervalidasi maka selanjutnya akan dibandingkan output kinerja ruas dengan parameter kecepatan setempat, kecepatan tempuh, dan kepadatan. Dengan demikian akan diperoleh gambaran yang lebih komprehensif mengenai efektivitas penerapan chicane di Indonesia.

\section{METODE PENELITIAN}

\section{Lokasi Penelitian}

Ersamaulia (2018) melakukan penelitiannya di Jalan Pemuda di Kabupaten Kebumen, Jawa Tengah, Indonesia. Karakteristik lokasi tersebut dinilai memiliki kesesuaian dengan kriteria lokasi chicane. Peta lokasi penelitian ditunjukkan pada Gambar 3.

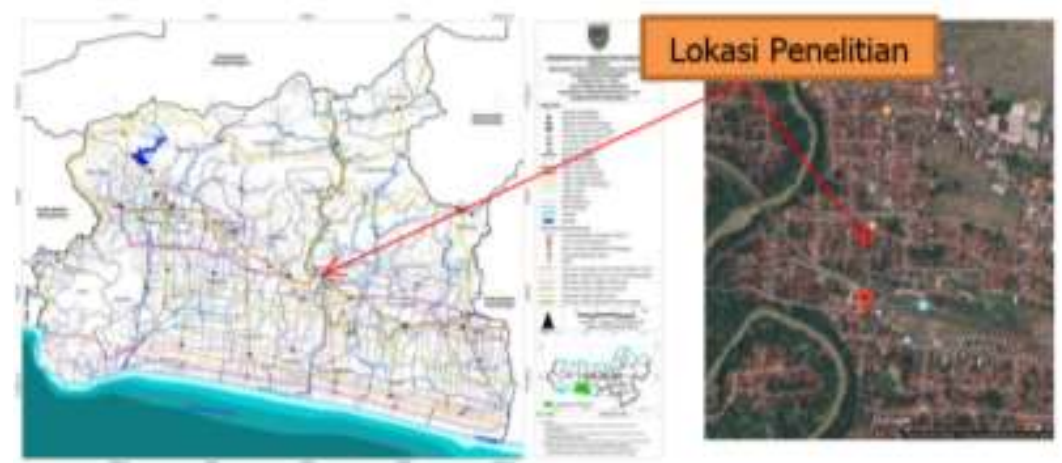

Gambar 1. Peta lokasi penelitian (Ersamaulia, 2018)

Jalan Pemuda mempunyai panjang jalan 1,6 kilometer dan lebar jalan 10 meter dengan kemiringan jalan 2\% (Ersamaulia, 2018). Tipe jalan Pemuda adalah 2/2 UD yang artinya adalah dua lajur dengan dua arah tanpa median. Lebar bahu kanan 0,9 meter 
dan lebar bahu kiri 0,4 meter. Trotoar pada sisi kanan memiliki lebar 1,5 meter dan trotoar pada sisi kiri memiliki lebar 1,7 meter. Pada jalan Pemuda terdapat drainase pada sisi sebelah kiri atau timur dengan lebar 4 meter. Pada lokasi penelitian tidak terdapat pengaturan parkir. Kondisi perkerasan Jalan Pemuda dalam kondisi baik. Kendaraan yang melintas di Jalan Pemuda didominasi sepeda motor dan kendaraan ringan. Kondisi lokasi dan ditunjukkan oleh Gambar 4.

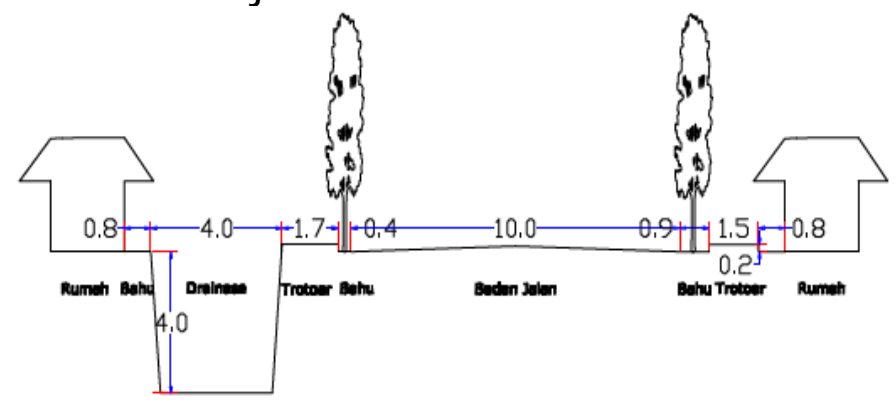

Gambar 2. Kondisi lokasi penelitian (Ersamaulia, 2018)

\section{Metode Pengumpulan Data}

Data yang digunakan dalam penelitian ini merupakan data sekunder dari penelitian mengenai efektivitas penerapan chicane untuk mengurangi kecepatan kendaraan yang dilakukan oleh Ersamaulia (2018). Data inilah yang akan dipakai dalam pembuatan model simulasi lalu lintas serta validasinya dalam penelitian ini. Adapun data-data tersebut adalah data geometrik jalan, volume lalu lintas, dan kecepatan kendaraan.

\section{Metode Analisis Data}

Dalam penelitian ini data akan dianalisis secara deskriptif. Adapun langkah-langkah yang akan dilakukan adalah sebagai berikut:

a. Data sekunder dari penelitian Ersamaulia (2018) berupa data geometrik, volume kendaraan, data kecepatan sebelum maupun setelah penerapan chicane, direkap menggunakan Ms. Excel dalam bentuk tabel dan grafik.

b. Pembuatan model simulasi VISSIM, yaitu dengan cara:

1) Membuat link dan connector

2) Menginput base data, yaitu jenis kendaraan pada 2D/3D models, vehicle types dan vehicle classes, desired speed distribution serta vehicle compositions

3) Menginput volume lalu lintas pada vehicle inputs

4) Menentukan rute perjalanan pada static vehicle routing decisions

5) Melakukan kalibrasi dengan metode trial and error dengan mengubah nilai parameter perilaku pengemudi (driving behavior)

6) Menjalankan simulasi

c. Melakukan validasi model dengan menggunakan rumus GEH dan MAPE

d. Melakukan perbandingan kinerja lalu lintas pada kondisi eksisting maupun penerapan kedua model chicane, dengan parameter kecepatan tempuh dan kepadatan. Validasi model akan dilakukan dengan menggunakan rumus GEH dan MAPE (dalam Putri \& Irawan, 2015).

\section{HASIL DAN PEMBAHASAN}

Pembuatan Model

Langkah pertama dalam pembuatan model dengan menggunakan software VISSIM ini adalah membuat link dan connector yang kemudian dilanjutkan dengan menginput 
database. Link yang dibuat sesuai dengan lokasi studi pada penelitian sebelumnya oleh Ersamaulia (2018), yaitu sepanjang 300 meter. Data yang digunakan juga merupakan data hasil survei pada penelitian tersebut. Data yang digunakan meliputi data geometrik jalan, komposisi kendaraan, volume kendaraan, dan kecepatan kendaraan. Data-data tersebut dimasukkan dalam menu vehicle types, vehicle classes, desired speed distribution, vehicle compositions, serta volume lalu lintas. Setelah itu dilakukan penentuan rute perjalanan pada static vehicle routing decisions.

Langkah berikutnya adalah melakukan kalibrasi dengan mengubah nilai parameter perilaku pengemudi (driving behavior). Penelitian ini mengacu pada nilai parameter perilaku pengemudi dalam studi (Putri \& Irawan, 2015). Validasi model dilakukan dengan membandingkan volume dan kecepatan hasil observasi dengan output model menggunakan rumus GEH dan MAPE. Proses kalibrasi dapat dilihat pada Tabel 1.

Tabel 1. Proses Kalibrasi (Putri \& Irawan, 2015)

\begin{tabular}{|c|c|c|c|}
\hline \multirow{2}{*}{$\begin{array}{c}\text { Kalibrasi } \\
\text { ke- }\end{array}$} & \multirow{2}{*}{ Parameter yang diubah } & \multicolumn{2}{|c|}{ Nilai } \\
\hline & & Sebelum & Sesudah \\
\hline \multirow[t]{3}{*}{1} & 1. Desired position at free flow & Middle of lane & Any \\
\hline & $\begin{array}{l}\text { 2. Overtake on same lane: on left \& on } \\
\text { right }\end{array}$ & Off & On \\
\hline & (lanjut dari tria/ke-1) & & \\
\hline \multirow[t]{2}{*}{2} & 1. Distance standing $($ at $0 \mathrm{~km} / \mathrm{h})(\mathrm{m})$ & 1 & 0,2 \\
\hline & 2. Distance driving (at $50 \mathrm{~km} / \mathrm{h})(\mathrm{m})$ & 1 & 0,4 \\
\hline \multirow{4}{*}{3} & (lanjut dari trial ke-2) & & \\
\hline & 1. Average standstill distance & 2 & 1 \\
\hline & 2. Additive part of safety distance & 2 & 1 \\
\hline & 3. Multiplicative part of safety distance & 3 & 2 \\
\hline \multirow{4}{*}{4} & (lanjut dari tria/ke-3) & & \\
\hline & 1. Average standstill distance & 1 & 0,5 \\
\hline & 2. Additive part of safety distance & 1 & 0,5 \\
\hline & 3. Multiplicative part of safety distance & 2 & 1 \\
\hline \multirow{4}{*}{5} & (lanjut dari tria/ke-4) & & \\
\hline & 1. Average standstill distance & 0,5 & 0,6 \\
\hline & 2. Additive part of safety distance & 0,5 & 0,6 \\
\hline & 3. Multiplicative part of safety distance & 1 & 1 \\
\hline
\end{tabular}

Sebagaimana telah disampaian di atas, setelah kalibrasi dilakukan maka selanjutnya dilakukan validasi model, yaitu dengan cara membandingkan volume dan kecepatan kendaraan hasil observasi dengan output model menggunakan rumus GEH dan MAPE. Hasil kalibrasi yang disampaikan disini adalah hasil kalibrasi terbaik, yaitu trial kelima yang telah disampaikan sebelumnya pada Tabel 1 . Hasil uji GEH dan MAPE untuk volume dan kecepatan pada simulasi kondisi eksisting dapat dilihat pada Tabel 2 dan Tabel 3. 
Tabel 2. Hasil Uji GEH dan MAPE untuk volume kendaraan pada simulasi kondisi eksisting

\begin{tabular}{|c|c|c|c|c|c|c|c|}
\hline \multirow[b]{2}{*}{ Kondisi } & \multirow[b]{2}{*}{ Kendaraan } & \multicolumn{2}{|c|}{ Hasil Uji GEH } & \multirow[b]{2}{*}{ Kesimpulan } & \multicolumn{2}{|c|}{ Uji MAPE } & \multirow[b]{2}{*}{ Kesimpular } \\
\hline & & $\begin{array}{l}\text { Arah } \\
\text { U-S }\end{array}$ & $\begin{array}{l}\text { Arah } \\
\text { S-U }\end{array}$ & & $\begin{array}{l}\text { Arah } \\
\text { U-S }\end{array}$ & $\begin{array}{c}\text { Arah } \\
\text { S-U }\end{array}$ & \\
\hline \multirow[t]{4}{*}{ Default } & $\begin{array}{l}\text { Sepeda } \\
\text { motor }\end{array}$ & 654,59 & 30,81 & \multirow[t]{4}{*}{ Ditolak } & $42 \%$ & $32 \%$ & \multirow[t]{4}{*}{ Diterima } \\
\hline & $\begin{array}{l}\text { Kendaraan } \\
\text { ringan }\end{array}$ & 60,25 & 13,16 & & $42 \%$ & $23 \%$ & \\
\hline & $\begin{array}{l}\text { Kendaraan } \\
\text { berat }\end{array}$ & 0,11 & 1,64 & & $10 \%$ & $43 \%$ & \\
\hline & Total & 713,29 & 321,22 & & $41 \%$ & $31 \%$ & \\
\hline \multirow[t]{4}{*}{$\begin{array}{c}\text { Hasil } \\
\text { kalibrasi }\end{array}$} & $\begin{array}{l}\text { Sepeda } \\
\text { motor }\end{array}$ & 0,05 & 0,03 & \multirow[t]{4}{*}{ Diterima } & $0 \%$ & $0 \%$ & \multirow[t]{4}{*}{ Diterima } \\
\hline & $\begin{array}{l}\text { Kendaraan } \\
\text { ringan }\end{array}$ & 0,03 & 0,22 & & $1 \%$ & $3 \%$ & \\
\hline & $\begin{array}{l}\text { Kendaraan } \\
\text { berat }\end{array}$ & 0,78 & 1,64 & & $30 \%$ & $43 \%$ & \\
\hline & Total & 0,01 & 0,01 & & $0 \%$ & $0 \%$ & \\
\hline
\end{tabular}

Tabel 3. Hasil Uji GEH dan MAPE untuk kecepatan kendaraan pada simulasi kondisi eksisting

\begin{tabular}{|c|c|c|c|c|c|c|c|}
\hline \multirow[b]{2}{*}{ Kondisi } & \multirow[b]{2}{*}{ Kendaraan } & \multicolumn{3}{|c|}{ Hasil Uji GEH } & \multicolumn{3}{|c|}{ Hasil Uji MAPE } \\
\hline & & $\begin{array}{c}\text { Arah } \\
\text { U-S }\end{array}$ & $\begin{array}{c}\text { Arah } \\
\text { S-U }\end{array}$ & Kesimpulan & $\begin{array}{l}\text { Arah } \\
\text { U-S }\end{array}$ & $\begin{array}{c}\text { Arah } \\
\text { S-U }\end{array}$ & Kesimpulan \\
\hline \multirow[t]{4}{*}{ Default } & $\begin{array}{l}\text { Sepeda } \\
\text { motor }\end{array}$ & 5,40 & 3,89 & Diterima & $31 \%$ & $27 \%$ & Diterima \\
\hline & $\begin{array}{l}\text { Kendaraan } \\
\text { ringan }\end{array}$ & 2,82 & 2,59 & & $24 \%$ & $23 \%$ & \\
\hline & $\begin{array}{l}\text { Kendaraan } \\
\text { berat }\end{array}$ & 1,54 & 0,83 & & $19 \%$ & $14 \%$ & \\
\hline & Total & 2,71 & 1,79 & & $24 \%$ & $20 \%$ & \\
\hline \multirow[t]{4}{*}{$\begin{array}{c}\text { Hasil } \\
\text { kalibrasi }\end{array}$} & $\begin{array}{l}\text { Sepeda } \\
\text { motor }\end{array}$ & 0,28 & 0,10 & Diterima & $8 \%$ & $5 \%$ & Diterima \\
\hline & $\begin{array}{l}\text { Kendaraan } \\
\text { ringan }\end{array}$ & 0,19 & 0,08 & & $6 \%$ & $4 \%$ & \\
\hline & $\begin{array}{l}\text { Kendaraan } \\
\text { berat }\end{array}$ & 0,37 & 0,38 & & $9 \%$ & $10 \%$ & \\
\hline & Total Kend. & 0,01 & 0,08 & & $2 \%$ & $5 \%$ & \\
\hline
\end{tabular}

Berdasarkan Tabel 2 dan Tabel 3 di atas, diketahui bahwa hasil validasi baik untuk hasil kalibrasi volume maupun kecepatan, baik untuk uji GEH maupun MAPE, mendapat hasil diterima. Hal ini ditunjukkan dari nilai GEH volume dan kecepatan kurang dari 5 dan nilai MAPE kurang dari 50\%. Hal ini berlaku untuk setiap jenis kendaraan maupun total kendaraan.

Hasil uji GEH untuk volume default masih menunjukkan nilai $>5$ untuk sepeda motor, kendaraan ringan dan total kendaraan. Hasil uji MAPE sebenarnya sudah menunjukkan nilai kurang dari 50\%, namun karena validasi dilakukan melalui uji GEH dan MAPE 
maka model hasil kalibrasi yang akan digunakan. Demikian pula dengan kecepatan, walaupun uji GEH dan MAPE sudah dapat diterima pada kondisi default, namun karena model hasil kalibrasi menunjukkan hasil yang lebih baik (nilai lebih kecil) maka yang digunakan adalah model hasil kalibrasi. Visualisasi model hasil kalibrasi pada kondisi eksisting dapat dilihat pada Gambar 5.

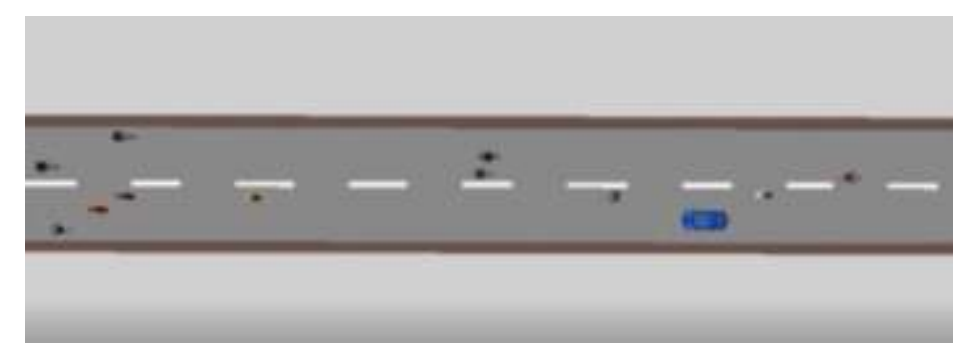

Gambar 3. Visualisasi hasil kalibrasi kondisi eksisting

Langkah-langkah dalam pembuatan model penerapan chicane model 1 dan chicane model 2 sama dengan pembuatan model pada kondisi eksisting. Hanya saja terdapat penerapan chicane yang menggunakan dimensi chicane sebagaimana telah disampaikan di atas. Pada area 1, 2, dan 3 di daerah chicane diterapkan reduced speed area sebesar pengurangan kecepatan sebagaimana pada penelitian Ersamaulia (2018). Area 1 merupakan area sepanjang 50 meter sebelum memasuki chicane, area 2 merupaka area sepanjang 10 meter di dalam chicane, dan area 3 merupakan area sepanjang 50 meter setelah keluar dari chicane. Tabel 4 menunjukkan pengurangan kecepatan yang digunakan dalam pembuatan simulasi chicane model 1 dan model 2 .

Tabel 4. Pengurangan kecepatan

\begin{tabular}{ccccc}
\hline \multirow{2}{*}{ Model } & \multirow{2}{*}{ Arah } & \multicolumn{3}{c}{ Pengurangan Kecepatan (\%) } \\
\cline { 3 - 5 } & & Area 1 & Area 2 & Area 3 \\
\hline Model 1 & U-S & 7 & 20 & 15 \\
\cline { 2 - 5 } & S-U & 6 & 17 & 13 \\
\hline Model 2 & U-S & 20 & 38 & 20 \\
& S-U & 17 & 40 & 23 \\
\hline
\end{tabular}

Proses kalibrasi dilakukan dengan mengubah nilai parameter perilaku pengemudi (driving behavior) dengan menggunakan parameter yang sama dengan simulasi pada kondisi eksisting. Selanjutnya juga dilakukan validasi dengan menguji menggunakan rumus GEH dan MAPE baik untuk volume maupun kecepatan. Hasil uji GEH dan MAPE untuk volume dan kecepatan pada simulasi penerapan chicane model 1 dapat dilihat pada Tabel 5 dan Tabel 6. 
Tabel 5. Hasil Uji GEH dan MAPE untuk volume kendaraan pada simulasi penerapan chicane model 1

\begin{tabular}{|c|c|c|c|c|c|c|c|}
\hline \multirow[t]{2}{*}{ Kondisi } & \multirow[t]{2}{*}{ Kendaraan } & \multicolumn{2}{|c|}{ Hasil Uji GEH } & \multirow[t]{2}{*}{ Kesimpulan } & \multicolumn{2}{|c|}{ Uji MAPE } & \multirow[t]{2}{*}{ Kesimpulan } \\
\hline & & $\begin{array}{c}\text { Arah } \\
\text { U-S }\end{array}$ & $\begin{array}{c}\text { Arah } \\
\text { S-U }\end{array}$ & & $\begin{array}{c}\text { Arah } \\
\text { U-S }\end{array}$ & $\begin{array}{c}\text { Arah } \\
\text { S-U }\end{array}$ & \\
\hline \multirow[t]{4}{*}{ Default } & $\begin{array}{l}\text { Sepeda } \\
\text { motor }\end{array}$ & 421,24 & 285,52 & \multirow[t]{4}{*}{ Ditolak } & $34 \%$ & $31 \%$ & \multirow[t]{4}{*}{ Diterima } \\
\hline & $\begin{array}{l}\text { Kendaraan } \\
\text { ringan }\end{array}$ & 85,50 & 12,06 & & $48 \%$ & $22 \%$ & \\
\hline & $\begin{array}{l}\text { Kendaraan } \\
\text { berat }\end{array}$ & 0,00 & 1,64 & & $0 \%$ & $43 \%$ & \\
\hline & Total & 494,89 & 296,93 & & $35 \%$ & $30 \%$ & \\
\hline \multirow[t]{4}{*}{$\begin{array}{c}\text { Hasil } \\
\text { kalibrasi }\end{array}$} & $\begin{array}{l}\text { Sepeda } \\
\text { motor }\end{array}$ & 0,48 & 0,08 & \multirow[t]{4}{*}{ Diterima } & $1 \%$ & $1 \%$ & \multirow[t]{4}{*}{ Diterima } \\
\hline & $\begin{array}{l}\text { Kendaraan } \\
\text { ringan }\end{array}$ & 3,92 & 0,17 & & $12 \%$ & $3 \%$ & \\
\hline & $\begin{array}{l}\text { Kendaraan } \\
\text { berat }\end{array}$ & 1,33 & 1,64 & & $40 \%$ & $43 \%$ & \\
\hline & Total & 0,03 & 0,04 & & $0 \%$ & $0 \%$ & \\
\hline
\end{tabular}

Tabel 6. Hasil Uji GEH dan MAPE untuk kecepatan kendaraan pada simulasi penerapan chicane model 1

\begin{tabular}{|c|c|c|c|c|c|c|c|}
\hline \multirow[t]{2}{*}{ Kondisi } & \multirow[t]{2}{*}{ Kendaraan } & \multicolumn{3}{|c|}{ Hasil Uji GEH } & \multicolumn{3}{|c|}{ Hasil Uji MAPE } \\
\hline & & $\begin{array}{c}\text { Arah } \\
\text { U-S }\end{array}$ & $\begin{array}{c}\text { Arah } \\
\text { S-U }\end{array}$ & Kesimpulan & $\begin{array}{c}\text { Arah } \\
\text { U-S }\end{array}$ & $\begin{array}{c}\text { Arah } \\
\text { S-U }\end{array}$ & Kesimpulan \\
\hline \multirow[t]{4}{*}{ Default } & $\begin{array}{l}\text { Sepeda } \\
\text { motor }\end{array}$ & 0,35 & 0,37 & Diterima & $10 \%$ & $9 \%$ & Diterima \\
\hline & $\begin{array}{l}\text { Kendaraan } \\
\text { ringan }\end{array}$ & 0,21 & 0,01 & & $8 \%$ & $2 \%$ & \\
\hline & $\begin{array}{l}\text { Kendaraan } \\
\text { berat }\end{array}$ & 0,19 & 0,06 & & $8 \%$ & $5 \%$ & \\
\hline & Total & 0,25 & 0,01 & & $8 \%$ & $2 \%$ & \\
\hline \multirow[t]{4}{*}{$\begin{array}{c}\text { Hasil } \\
\text { kalibrasi }\end{array}$} & $\begin{array}{l}\text { Sepeda } \\
\text { motor }\end{array}$ & 1,28 & 0,03 & Diterima & $19 \%$ & $3 \%$ & Diterima \\
\hline & $\begin{array}{l}\text { Kendaraan } \\
\text { ringan }\end{array}$ & 0,26 & 0,38 & & $8 \%$ & $11 \%$ & \\
\hline & $\begin{array}{l}\text { Kendaraan } \\
\text { berat }\end{array}$ & 0,28 & 0,09 & & $9 \%$ & $6 \%$ & \\
\hline & Total Kend. & 0,53 & 0,13 & & $12 \%$ & $6 \%$ & \\
\hline
\end{tabular}

Sebagaimana pada simulasi kondisi eksisting, pada simulasi penerapan chicane model 1 ini kecepatan default telah menunjukkan nilai GEH kurang dari 5 dan MAPE kurang dari $50 \%$, sehingga hasil sebenarnya sudah dapat diterima. Hasil kalibrasi kecepatan juga menunjukkan nilai GEH dan MAPE yang sedikit lebih besar dibanding dengan default. Namun demikian, dikarenakan nilai GEH default volume masih menunjukkan nilai lebih dari 5 (ditolak) maka yang digunakan adalah hasil kalibrasi. Visualisasi simulasi penerpaan chicane model 1 hasil kalibrasi dapat dilihat pada Gambar 6. 


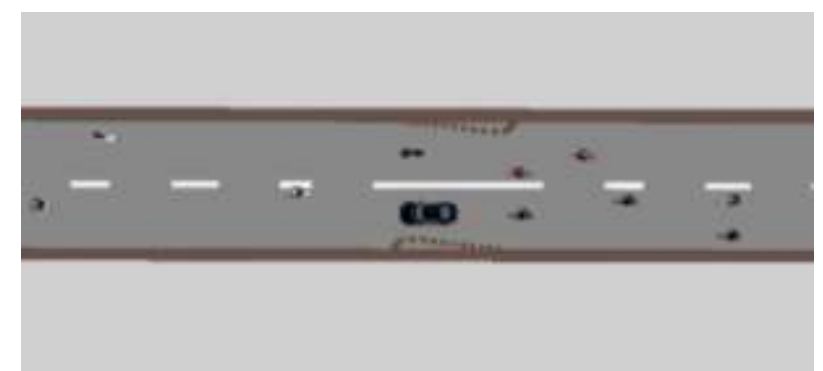

Gambar 4. Visualisasi simulasi penerapan chicane model 1 hasil kalibrasi

Hasil uji GEH dan MAPE untuk volume dan kecepatan pada simulasi penerapan chicane model 2 dapat dilihat pada Tabel 7 dan Tabel 8.

Tabel 7. Hasil Uji GEH dan MAPE untuk volume kendaraan pada simulasi chicane model 2

\begin{tabular}{|c|c|c|c|c|c|c|c|}
\hline \multirow[t]{2}{*}{ Kondisi } & \multirow[t]{2}{*}{ Kendaraan } & \multicolumn{2}{|c|}{ Hasil Uji GEH } & \multirow[t]{2}{*}{ Kesimpulan } & \multicolumn{2}{|c|}{ Uji MAPE } & \multirow[t]{2}{*}{ Kesimpulan } \\
\hline & & $\begin{array}{c}\text { Arah U- } \\
\mathbf{S}\end{array}$ & $\begin{array}{c}\text { Arah } \\
\text { S-U }\end{array}$ & & $\begin{array}{c}\text { Arah } \\
\text { U-S }\end{array}$ & $\begin{array}{c}\text { Arah } \\
\text { S-U }\end{array}$ & \\
\hline \multirow[t]{4}{*}{ Default } & $\begin{array}{l}\text { Sepeda } \\
\text { motor }\end{array}$ & $1.246,65$ & 420,94 & Ditolak & $55 \%$ & $36 \%$ & \multirow{4}{*}{$\begin{array}{l}\text { Ditolak (US); } \\
\text { diterima } \\
\text { (SU) }\end{array}$} \\
\hline & $\begin{array}{l}\text { Kendaraan } \\
\text { ringan }\end{array}$ & 161,61 & 17,42 & & $63 \%$ & $27 \%$ & \\
\hline & $\begin{array}{l}\text { Kendaraan } \\
\text { berat }\end{array}$ & 0,44 & 1,64 & & $20 \%$ & $43 \%$ & \\
\hline & Total & $1.401,08$ & 436,60 & & $55 \%$ & $36 \%$ & \\
\hline \multirow[t]{4}{*}{$\begin{array}{c}\text { Hasil } \\
\text { kalibrasi }\end{array}$} & $\begin{array}{l}\text { Sepeda } \\
\text { motor }\end{array}$ & 0,38 & 0,03 & Diterima & $1 \%$ & $0 \%$ & \multirow[t]{4}{*}{ Diterima } \\
\hline & $\begin{array}{l}\text { Kendaraan } \\
\text { ringan }\end{array}$ & 3,92 & 0,22 & & $12 \%$ & $3 \%$ & \\
\hline & $\begin{array}{l}\text { Kendaraan } \\
\text { berat }\end{array}$ & 1,33 & 1,64 & & $40 \%$ & $43 \%$ & \\
\hline & Total & 0,01 & 0,01 & & $0 \%$ & $0 \%$ & \\
\hline
\end{tabular}

Tabel 8. Hasil Uji GEH dan MAPE untuk kecepatan kendaraan pada simulasi chicane model 2

\begin{tabular}{|c|c|c|c|c|c|c|c|}
\hline \multirow[t]{2}{*}{ Kondisi } & \multirow[t]{2}{*}{ Kendaraan } & \multicolumn{3}{|c|}{ Hasil Uji GEH } & \multicolumn{3}{|c|}{ Hasil Uji MAPE } \\
\hline & & $\begin{array}{c}\text { Arah } \\
\text { U-S }\end{array}$ & $\begin{array}{c}\text { Arah } \\
\text { S-U }\end{array}$ & Kesimpulan & $\begin{array}{c}\text { Arah } \\
\text { U-S }\end{array}$ & $\begin{array}{c}\text { Arah } \\
\text { S-U }\end{array}$ & Kesimpulan \\
\hline \multirow[t]{4}{*}{ Default } & $\begin{array}{l}\text { Sepeda } \\
\text { motor }\end{array}$ & 0,52 & 0,00 & \multirow[t]{4}{*}{ Diterima } & $15 \%$ & $0 \%$ & \multirow[t]{4}{*}{ Diterima } \\
\hline & $\begin{array}{l}\text { Kendaraan } \\
\text { ringan }\end{array}$ & 5,23 & 0,34 & & $39 \%$ & $12 \%$ & \\
\hline & $\begin{array}{l}\text { Kendaraan } \\
\text { berat }\end{array}$ & 3,92 & 0,82 & & $35 \%$ & $19 \%$ & \\
\hline & Total & 2,85 & 0,25 & & $31 \%$ & $10 \%$ & \\
\hline \multirow[t]{4}{*}{$\begin{array}{c}\text { Hasil } \\
\text { kalibrasi }\end{array}$} & $\begin{array}{l}\text { Sepeda } \\
\text { motor }\end{array}$ & 0,05 & 1,67 & \multirow[t]{4}{*}{ Diterima } & $5 \%$ & $26 \%$ & \multirow[t]{4}{*}{ Diterima } \\
\hline & $\begin{array}{l}\text { Kendaraan } \\
\text { ringan }\end{array}$ & 0,27 & 3,10 & & $10 \%$ & $38 \%$ & \\
\hline & $\begin{array}{l}\text { Kendaraan } \\
\text { berat }\end{array}$ & 0,64 & 2,05 & & $15 \%$ & $31 \%$ & \\
\hline & Total Kend. & 0,15 & 2,23 & & $8 \%$ & $32 \%$ & \\
\hline
\end{tabular}


Sebagaimana pada dua simulasi sebelumnya, pada simulasi penerapan chicane model 2 ini kecepatan default telah menunjukkan nilai GEH kurang dari 5 dan MAPE kurang dari $50 \%$ (diterima). Hasil kalibrasi kecepatan menunjukkan nilai GEH dan MAPE lebih besar untuk arah S-U. Dikarenakan nilai GEH default volume masih menunjukkan nilai lebih dari 5 (ditolak) maka yang digunakan adalah hasil kalibrasi. Visualisasi simulasi penerapan chicane model 2 hasil kalibrasi dapat dilihat pada Gambar 7.

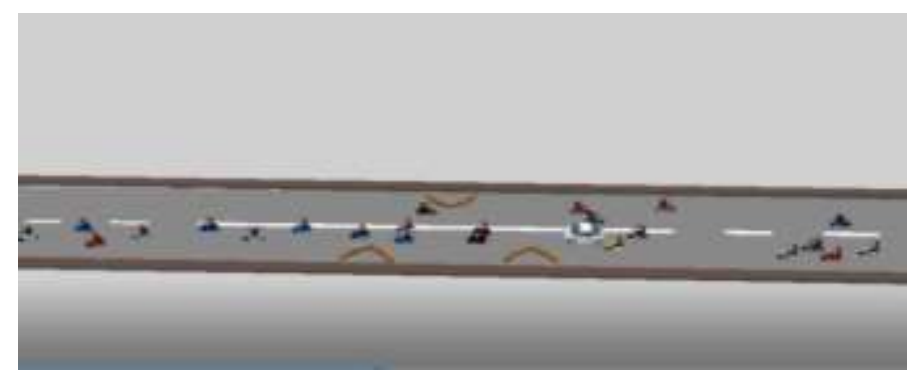

Gambar 5. Visualisasi simulasi penerapan chicane model 2 hasil kalibrasi

Berdasarkan hasil kalibrasi dan validasi sebagaimana dipaparkan di atas, maka dapat disimpulkan bahwa model hasil kalibrasi cukup merepresentasikan hasil observasi pada kondisi sebenarnya. Dengan demikian, ketiga model yang telah dibangun tersebut dapat digunakan untuk pembahasan lebih lanjut.

\section{Kinerja Ruas}

Setelah model untuk kondisi eksisting, chicane model 1, dan chicane model 2 terbangun, selanjutnya dilakukan perbandingan kinerja lalu lintas pada ketiga kondisi tersebut. Parameter kinerja yang akan dibandingkan adalah kecepatan setempat (kecepatan di area 2), kecepatan tempuh, dan kepadatan. Parameter kinerja tersebut disajikan pada Tabel 9, bersama dengan waktu tempuh dan tundaan.

Tabel 9. Perbandingan kinerja ruas jalan hasil simulasi VISSIM

\begin{tabular}{lccc}
\hline Parameter & \multicolumn{3}{c}{ Hasil Simulasi VISSIM } \\
\cline { 2 - 4 } & Eksisting & $\begin{array}{c}\text { Chicane } \\
\text { Model 1 }\end{array}$ & $\begin{array}{c}\text { Chicane } \\
\text { Model 2 }\end{array}$ \\
\hline $\begin{array}{l}\text { Kecepatan setempat area 2 arah U-S } \\
\text { (km/jam) }\end{array}$ & 40 & 41 & 23 \\
\hline $\begin{array}{l}\text { Kecepatan setempat area 2 arah S-U } \\
\text { (km/jam) }\end{array}$ & 40 & 36 & 34 \\
\hline Waktu tempuh arah U-S (dt) & 28 & 28 & 43 \\
\hline Waktu tempuh arah S-U (dt) & 28 & 32 & 34 \\
\hline Kecepatan tempuh arah U-S (km/jam) & 57 & 57 & 37 \\
\hline Kecepatan tempuh arah S-U (km/jam) & 56 & 50 & 47 \\
\hline Kepadatan (kend/km) & 24,18 & 25,83 & 36,05 \\
\hline Tundaan (dt) & 0,04 & 0,04 & 0,09 \\
\hline
\end{tabular}

Tabel 9 menunjukkan bahwa secara umum penerapan chicane, baik model 1 maupun model 2, menyebabkan penurunan kinerja ruas jalan. Perbandingan kecepatan setempat di area 2 menunjukkan bahwa penurunan kecepatan kendaraan pada saat penerapan chicane model 2 lebih signifikan. Pada saat penerapan chicane model 1 
bahkan terjadi sedikit kenaikan kecepatan menjadi $41 \mathrm{~km} / \mathrm{jam}$ atau sebesar $1 \mathrm{~km} / \mathrm{jam}$ (1\%) untuk arah U-S, walaupun tetap terjadi penurunan kecepatan setempat menjadi $36 \mathrm{~km} / \mathrm{jam}$ atau sebesar $3 \%$ untuk arah S-U. Kecepatan pada saat penerapan chicane model 2 turun menjadi $23 \mathrm{~km} / \mathrm{jam}$ atau sebesar $18 \mathrm{~km} / \mathrm{jam}(44 \%)$ untuk arah U-S dan $34 \mathrm{~km} / \mathrm{jam}$ atau sebesar $6 \mathrm{~km} / \mathrm{jam}(14 \%)$ untuk arah S-U.

Temuan ini sejalan dengan temuan pada parameter kinerja ruas jalan yang lain. Pada penerapan chicane model 1 kecepatan tempuh untuk arah U-S tidak mengalami perubahan dari kondisi eksisting, yaitu $57 \mathrm{~km} / \mathrm{jam}$, sedangkan untuk arah S-U mengalami penurunan dari $56 \mathrm{~km} / \mathrm{jam}$ menjadi $50 \mathrm{~km} / \mathrm{jam}$. Demkian pula dengan waktu tempuh, tetap 28 detik untuk arah U-S dan bertambah menjadi 32 detik untuk arah S-U. Penurunan kecepatan tempuh dan peningkatan waktu tempuh pada saat penerapan chicane 2 cukup tajam. Untuk arah U-S kecepatan tempuh kendaraan menjadi $37 \mathrm{~km} / \mathrm{jam}$ dan waktu tempuhnya menjadi 43 detik, sedangkan untuk arah S$\mathrm{U}$ kecepatan tempuh kendaraan menjadi $47 \mathrm{~km} / \mathrm{jam}$ dan waktu tempuhnya menjadi 34 detik.

Demikian pula untuk kepadatan dan tundaan. Pada penerapan chicane model 1 kepadatan kendaraan sedikit bertambah menjadi 25,83 kend/km dan tundaan tetap 0,04 detik. Pada penerapan chicane model 2 kepadatan kendaraan bertambah cukup signifikan menjadi $36,05 \mathrm{kend} / \mathrm{km}$ dan tundaan bertambah lebih dari dua kali lipat menjadi 0,09 detik.

\section{Pembahasan}

Berdasarkan pemaparan di atas, diketahui bahwa VISSIM dapat digunakan untuk mensimulasikan penerapan traffic calming, dalam penelitian ini adalah chicane. Model yang dibangun adalah kondisi eksisting sebelum diterapkannya chicane, penerapan chicane model 1 , dan penerapan chicane model 2. Pada model penerapan chicane digunakan data pengurangan kecepatan hasil observasi saat simulasi lapangan sebagai pengurangan kecepatan di reduced speed area pada model VISSIM. Reduced speed area meliputi area 1 (50 meter sebelum memasuki chicane), area 2 (10 meter di dalam chicane), dan area 3 (50 meter setelah keluar dari chicane).

Selanjutnya kalibrasi dilakukan dengan mengubah parameter driving behavior dengan merujuk pada penelitian sebelumnya. Validasi dilakukan menggunakan rumus GEH dan MAPE, dengan hasil nilai GEH di bawah 5 dan MAPE di bawah 50\%. Dengan demikian, model telah tervalidasi.

Berdasarkan analisis hasil simulasi VISSIM yang telah dilakukan, diketahui penurunan kinerja ruas jalan pada penerapan chicane model 1 tidak terlalu signifikan, bahkan kecepatan tempuh untuk arah U-S masih tetap sama dengan kondisi eksisting yaitu 57 $\mathrm{km} / \mathrm{jam}$ dan tundaan tetap 0,04 detik. Hasil yang berbeda terjadi pada penerapan chicane model 2. Dilihat dari semua parameter, penurunan kinerja ruas jalan pada penerapan chicane model 2 cukup signifikan. Arah U-S menunjukkan penurunan yang lebih tajam dibanding dengan arah S-U. Untuk arah U-S bahkan terjadi penurunan kecepatan setempat sampai dengan 44\% dan kecepatan tempuh sampai dengan 35\% serta peningkatan waktu tempuh sampai dengan 54\%. Selain itu kepadatan dan tundaan pun mengalami peningkatan yang tajam, yaitu sebesar $49 \%$ dan $125 \%$.

Dengan demikian dapat disimpulkan bahwa perbandingan kinerja ruas jalan dari ketiga simulasi, yang dilakukan dengan parameter kecepatan setempat, kecepatan tempuh, kepadatan, ditambah dengan waktu tempuh dan tundaan, menunjukkan bahwa secara 
umum penerapan chicane mengurangi kinerja ruas jalan. Kinerja ruas jalan pada chicane model 2 lebih buruk dibanding dengan chicane model 1 . Hasil ini sejalan dengan dengan penelitian terdahulu yang dirujuk oleh penelitian ini, yaitu penelitian oleh Ersamaulia (2018), walaupun angka yang dihasilkan tidaklah sama persis.

Sejalan dengan Ersamaulia (2018), jika dilihat dari perspektif keselamatan lalu lintas, maka chicane model 2 lebih disarankan dikarenakan kecepatan setempatnya telah mendekati target kecepatan $30 \mathrm{~km} / \mathrm{jam}$ (Kementerian Perhubungan Republik Indonesia, 2015). Sedikit berbeda dengan penelitian tersebut yang menggunakan kecepatan p85 sebagai acuan, pada penelitian ini menggunakan kecepatan rata-rata. Namun tetap bisa disimpulkan bahwa hasil kedua penelitian ini tetaplah sejalan.

Lebih lanjut, jika dilihat dari perspektif kelancaran lalu lintas maka penurunan kinerja ruas jalan yang cukup signifikan ini dikhawatirkan akan mengganggu arus lalu lintas pada jaringan jalan yang lebih luas. Suatu hal yang tidak bisa diukur oleh penelitian ini dikarenakan lokasi studi yang digambarkan dalam model VISSIM hanyalah berupa link sepanjang 300 meter saja.

Jaringan jalan yang terlalu sederhana ini agaknya juga berpengaruh pada proses kalibrasi dan validasi model yang dihasilkan VISSIM. Pada trial kedua sebenarnya sudah dapat dihasilkan nilai GEH dan MAPE yang memenuhi syarat. Namun untuk mendapatkan nilai yang optimal trial tetap dilanjutkan sampai trial terakhir dengan hasil terbaik. Bahkan unutk kondisi default pun diketemukan bahwa nilai GEH dan MAPE kecepatan sudah memenuhi syarat. Hal ini dimungkinkan oleh jaringan jalan pada model yang terlalu sederhana ini.

Selain terkait dengan terlalu sederhananya jaringan jalan pada model, penelitian ini juga memiliki catatan terkait dengan parameter driving behavioryang digunakan untuk kalibrasi. Parameter yang digunakan tersebut mengacu pada penelitian terdahulu dengan lokasi penelitian pada simpang (Putri \& Irawan, 2015). Pada lokasi studi ruas seperti halnya penelitian ini, hendaknya menggunakan parameter driving behavior tersebut dapat disesuaikan.

Terlepas dari kekurangan dalam pembuatan model dengan menggunakan VISSIM, penelitian ini membuktikan bahwa VISSIM dapat digunakan untuk memodelkan traffic calming dengan sejumlah catatan, terutama terkait proses kalibrasi dan validasi. Terbuka peluang chicane untuk dapat dijadikan alternatif traffic calming di Indonesia, dengan dilakukannya studi penerapannya di sejumlah lokasi yang lain.

Dengan melakukan simulasi dengan VISSIM peneliti juga akan lebih leluasa mementukan MOE yang dibutuhkan dalam studinya. Pada penelitian selanjutnya VISSIM juga dapat digunakan memodelkan dimensi chicane, ataupun memodelkan serial chicane di sebuah ruas jalan. Dengan demikian simulasi yang dilakukan dapat lebih efektif, efisien, dan aman, jika dibandingkan dengan simulasi lapangan.

\section{PENUTUP}

Penelitian ini menunjukkan bahwa VISSIM dapat digunakan untuk mensimulasikan traffic calming, dalam hal ini adalah chicane. Hasil simulasi VISSIM sejalan dengan hasil simulasi lapangan pada penelitian sbelumnya. Parameter kinerja seperti kecepatan setempat, kecepatan tempuh, kepadatan, maupun tundaan dapat secara serentak dianalisis sehingga simulasi lebih efektif, efisien, dan mengurangi risiko. Dengan ini pun maka peneliti dapat melakukan analisis lanjutan dengan lebih komprehensif. 
Meskipun terdapat kekurangan terkait terlalu sederhananya jaringan jalan yang dimodelkan dan parameter yang digunakan untuk kalibrasi, penelitian ini membuka peluang untuk penelitian lanjutan terkait dengan penerapan chicane sebagai traffic calming maupun penggunaan VISSIM sebagai alat bantu untuk melakukan simulasi lalu lintas.

\section{DAFTAR PUSTAKA}

Aghabayk, K., Sarvi, M., Young, W., \& Kautzsch, L. (2013). A Novel Methodology for Evolutionary Calibration of VISSIM by Multi-Threading. Australasian Transport Research Forum 2013 Proceedings, (October), 1-15. Diambil dari http://www.patrec.org/atrf.aspx

Basrin, D., Sugiarto, \& Anggraini, R. (2017). Studi Tingkat Pelayanan Simpang Tujuh Ulee Kareng Dengan Merencanakan Bundaran (Roundabout) Menggunakan Pendekatan Metode Simulasi Vissim 6.00-02. Jurnal Teknik Sipil Universitas Syiah Kuala, 1(1), 17-28.

Departemen Permukiman dan Prasarana Wilayah. (2004). Pedoman Perencanaan Fasilitas Pengendali Kecepatan Lalu Lintas. Jakarta: Direktorat Jenderal Prasarana Wilayah.

Dey, A. C., Roy, S., \& Uddin, M. A. (2018). Calibration and Validation of VISSIM Model of an Intersection with Modified Driving Behavior Parameter. International Journal of Advanced Research, 6(12), 107-112. https://doi.org/10.21474/IJAR01/8120

Direktorat Jendral Bina Marga. (1997). Manual Kapasitas Jalan Indonesia (MKJI). Jakarta: Departemen Pekerjaan Umum.

Ersamaulia, M. S. (2018). Penerapan Kelokan (Chicane) Sebagai Alat Pengendali Kecepatan (Studi Kasus: Jalan Pemuda Kabupaten Kebumen). Politeknik Keselamatan Transportasi Jalan.

Findley, D. J., Schroeder, B. J., Cunningham, C. M., \& Brown, T. H. (2016). Highway Engineering: Planning, Design, and Operations. Oxford: Elsevier.

Global Road Safety Partnership. (2008). Speed Management: A Road Safety Manual for Decision-Makers and Practitioners. https://doi.org/10.1016/B978-0-12802239-9.00007-4

Irawan, M. Z., \& Putri, N. H. (2015). Kalibrasi Vissim Untuk Mikrosimulasi Arus Lalu Lintas Tercampur Pada Simpang Bersinyal (Studi Kasus: Simpang Tugu, Yogyakarta). Jurnal Penelitian Transportasi Multimoda, 13(3), 97-106.

Kementerian Perhubungan. (2006). Peraturan Menteri Perhubungan Nomor KM 14 Tahun 2006 Tentang Manajemen dan Rekayasa Lalu Lintas di Jalan. Jakarta: Kementerian Perhubungan.

Kementerian Perhubungan. (2015). Peraturan Menteri Perhubungan Republik Indonesia Nomor PM 96 Tahun 2015 Tentang Pedoman Pelaksanaan Kegiatan Manajemen dan Rekayasa Lalu Lintas. Jakarta: Kementerian Perhubungan.

Kementerian Perhubungan Republik Indonesia. (2015). Peraturan Menteri Perhubungan Republik Indonesia Nomor PM 111 Tahun 2015 Tentang Tata Cara Penetapan Batas Kecepatan. Jakarta: Kementerian Perhubungan Republik Indonesia.

Khisty, C. J., \& Lall, B. K. (2003). Dasar-Dasar Rekayasa Transportasi. Jakarta: Erlangga. 
Misdalena, F. (2019). Evaluasi Kinerja Simpang Bersinyal Simpang Jakabaring Menggunakan Program Microsimulator VISSIM 8.00. Jurnal Desiminasi Teknologi, $71), 35-41$.

Pamusti, G., Maulana, A., \& Herman. (2017). Kinerja Simpang Jalan Jakarta-Jalan Supratman Kota Bandung dengan Metode MKJI 1997 dan Software PTV Vissim 9. Reka Racana, 3(3), 52-62.

Pennsylvania Department of Transportation. (2012). Pennsy/vania's Traffic Calming Handbook (Vol. 383). Vol. 383. Pennsylvania: Pennsylvania Department of Transportation.

PTV. (2011). VISSIM 5.30-05 User Manual. Diambil dari https://www.et.byu.edu/ msaito/CE662MS/Labs/VISSIM_530_e.pdf

Putra, R. A. E., \& Ramanda, F. (2018). Optimasi Green Time Simpang Bersinyal Dengan Menggunakan PTV VISSIM Dalam Meningkatkan Kinerja Simpang. Bentang Jurnal Teoritis dan Terapan Bidang Rekayasa Sipil, 6(2), 108-117.

Putri, N. H., \& Irawan, M. Z. (2015). Mikrosimulasi Mixed Traffic Pada Simpang Bersinyal Dengan Perangkat Lunak Vissim. The 18th FSTPT International Symposium. Lampung.

Romadhona, P. J. (2018). Solusi Jalan Satu Arah di Kota Yogyakarta. Teknik, 39(1), 25-31. https://doi.org/10.14710/teknik.v39i1.13654

Romadhona, P. J., \& Fauzi, R. I. (2018). Analisis Dampak Gang pada Putaran Balik Terhadap Kinerja Ruas Jalan Raya Affandi Yogyakarta. Jurnal Teknologi Rekayasa, 3(1), 29. https://doi.org/10.31544/jtera.v3.i1.2018.29-38

Sugiarto, S., Faisal, R., \& Reyhan, M. (2018). Pengaruh Sepeda Motor Terhadap Kapasitas Bagian Jalinan pada Perencanaan Bundaran di Simpang Tujuh Ulee Kareng. Teras Jurnal, 8(2), 416-425.

Utomo, R. B., Yulianyahya, R. W., \& Fauziah, M. (2016). Evaluasi Perilaku Lalu Lintas Pada Simpang Dan Koordinasi Antar Simpang (Studi Kasus: Simpang Stasiun Brambanan-Simpang Taman Wisata Candi). Jurnal Teknisia, XXI(1), 163-172.

Winnetou, I. A., \& Munawar, A. (2015). Penggunaan Software Vissim Untuk Evaluasi Hitungan MKJI 1997 Kinerja Ruas Jalan Perkotaan (Studi Kasus: Jalan Affandi, Yogyakarta). The 18th FSTPT International Symposium, Unila, Bandar Lampung.

Yulianto, R. A., \& Munawar, A. (2017). Penentuan Kapasitas Jalan Bebas Hambatan dengan Aplikasi Perangkat Lunak VISSIM. Jurnal Transportasi, 172), 123-132. 